6. Зевако Ю.В. Технологии конструирования политической идентичности в полиэтнической среде Российский империи // Известия Саратовского университета. Сер. Социология, политология. 2012. Т. 12, вып. 1. С. 113-118.

7. Положение об управлении областей Акмолинской, Семипалатинской, Семиреченской, Уральской и Тургайской. Верный: Типография губернского правления, 1895.

8. Свод главнейших законоположений и распоряжений о начальных народных училищах и учительских семинариях. Ч. 2. СПб.: Типография Сената, $1886.561 \mathrm{c.}$

9. Богуславский М.В. Реформы российского образования в России // Вопросы образования. 2006. № 3. C. 5-21.

10. Центральная Азия в составе Российской империи. М.: Новое литературное обозрение, 2008. 602 с.

11. Ильминский Н.И. Воспоминания об И.А. Алтынсарине. Казань: Казанская губернская типография, 1891. 202 с.
12. Стурова М.В. Образовательная среда на территории Акмолинской и Семипалатинской областей (50-е - 80-е гг. XIX в.) // Известия Алтайского государственного ун-та. Серия: История, политология. 2013. № 4/2 (80). C. 21-25.

13. Положение о почетных блюстителях при аульных школах Тургайской области // Тургайская газета. 1896. № 79. С. 2.

14. Циркуляр по Оренбургскому учебному округу № 8 за 1897 г. // Циркуляры по Оренбургскому учебному округу. 1897. № 1. С. 295-306.

15. Инородческие и иноверческие училища. Систематический свод законов / сост. Г. Фальборк, В. Чернокуский. СПб.: Право, 1902. 312 с.

16. Алтынсарин И. Записки о киргизских волостных школах // Собрание сочинений: в 3 т. Т. 2. АлмаАта: Государственное издательство Казахской ССР, 1975. C. 305-347.

17. Косач Г. Ибрагим Алтынсарин: человек в потоке времени // Вестник Евразии. 1998. № 1-2. C. $118-127$.

\title{
EDUCATIONAL POLICY OF THE RUSSIAN EMPIRE AND KAZAKH INTELLIGENTSIA FORMATION ON THE ORENBURG KRAI TERRITORY IN THE SECOND HALF OF THE XIX CENTURY
}

(C) 2018

\author{
Lyubichankovskiy Sergey Valentinovich, doctor of historical sciences, professor, \\ head of History of Russia Department \\ Orenburg State Pedagogical University (Orenburg, Russian Federation)
}

Abstract. The paper analyzes the changes that occurred in the second half of the XIX century on the territory of the Orenburg Region in relation to the education system in the Kazakh environment. The role of these changes is shown both for the implementation of the imperial policy of acculturation, and for the formation of the Kazakh intelligentsia. The author examined the formation of the Kazakh intelligentsia on the territory of the Orenburg Region as a result of the Kazakh ethnos westernization under the influence of Russian-secular education and public education in this region. It is concluded that with the establishment of the Special Committee for Foreign Education (1866) under the administration of the Kazan Academic District, the Empire took a course toward Russification, which can be interpreted as restricting the cultural identity of the ethnic region and enhancing the use of the Russian language, literature, orthodoxy. The main emphasis was placed on education. The imperial authorities implemented the idea that a single and stable multinational state is possible only if there is a strong ideological base, based on the Russified system of public education. As a result, gradually in late imperial Russia there was a concept of expanding the «alien» education with the help of enlightened «aliens». Gradually a stratum began to form that consisted of Kazakhs who, participating in the cause of education and dedication, supported the government, introduced representatives of the Kazakh ethnos to the expansion of the network of schools, they were educators and teachers. The process of creating schools for «aliens» implicitly led to the emergence of the Kazakh intelligentsia, which further exacerbated the national Kazakh movement within the Russian Empire.

Keywords: Orenburg Region; Russian Empire; Kazakhs; intelligentsia; foreigners; Russian-foreign schools; regional administration; national policy; educational policy; education; post-reform Russia; late imperial Russia; westernization; ideology; Russification.

УДК 94 (47).08: [266.3:273.99] (470.56) (093.2)

DOI 10.24411/2309-4370-2018-14216

Статья поступила в редакцию 08.07.2018

\section{АРХИВНЫЕ ИСТОЧНИКИ ПО ИСТОРИИ МИССИОНЕРСКОЙ ДЕЯТЕЛЬНОСТИ РУССКОЙ ПРАВОСЛАВНОЙ ЦЕРКВИ СРЕДИ СТАРООБРЯДЧЕСТВА ОРЕНБУРГСКОЙ ЕПАРХИИ ВТОРОЙ ПОЛОВИНЫ ХІХ - НАЧАЛА ХХ ВЕКОВ}

(C) 2018

Камзина Алина Джанаровна, кандидат исторических наук, доцент кафедры истории России Оренбургский государственный педагогический университет (г. Оренбург, Российская Федерация)

Аннотация. Рассматриваемый в данной статье исторический период является одним из важных периодов экономического, политического и духовного развития Российского государства. Оренбургский край на этом этапе представлял собой поликонфессиональный регион, где, несмотря на ведущую роль Русской православной церкви, распространение получили конфессии как нехристианского, так и христианского направления, в том числе разнообразные старообрядческие согласия и сектантство. В связи с этим особую актуальность 
Камзина А.Д.

Архивные источники по истории миссионерской деятельности Русской..

07.00.00 - исторические науки и археология

приобрела противораскольническая миссионерская деятельность официального православия, направленная одновременно на староверов и сектантов. Архивные документы, находящиеся в фондах федеральных и региональных архивов, составляют основу исследования этой проблемы. В статье представлен обзор неопубликованных источников и их источниковедческий анализ. Приводятся такие группы архивных источников, как статистические материалы, делопроизводственные источники, среди которых особое место занимают губернаторские и епархиальные отчеты, документы личного происхождения, законодательные материалы. Среди указанных групп источников наибольшую ценность представляют делопроизводственные материалы гражданского и духовного ведомств. Проведенный обзор позволяет сделать вывод о разнообразии видов архивных документов и их различных информативных возможностях. Представленная классификация не является окончательной и может быть дополнена.

Ключевые слова: Русская православная церковь; архивные источники; православное миссионерство; старообрядчество; сектантство; статистические документы; делопроизводственные источники; миссионер; Оренбургская епархия; епархиальный отчет; губернаторский отчет; православное миссионерское братство.

История миссионерской деятельности Русской православной церкви во всех ее проявлениях не стала исключением из ряда всех прочих тем, связанных с религиозной составляющей истории России. Она оказывалась фактически беззащитной перед сменяющими друг друга концепциями понимания и объяснения сути миссионерства Русской православной церкви. Отсюда понятно стремление исследователей опереться на реальные факты, сохраненные в архивных документах. Мы согласны со сложившимся определением в современной исторической науке о наступившем «веке подлинников», обращение к которым может приблизить к рациональному пониманию прошлого [1-3].

Но здесь обнаруживается не менее сложная проблема: ориентация в архивном массиве, сопоставление, дополнение, определение релевантности и т.д. Это и определило цель работы: дать характеристику различным видам источников, освещающих заявленную нами проблему, тем более что архивные массивы, касающиеся истории миссионерской деятельности Оренбургской епархии, достаточно своеобразны.

Миссионерская деятельность является одной из форм религиозной деятельности христианских конфессий. Миссионерство догматически обусловлено, в основе его лежит заповедь Христа, на которую ссылаются его адепты. Христос наставлял своих учеников: «Итак, идите, научите все народы, крестя их во имя Отца и Сына и Святого Духа, уча их соблюдать все, что Я повелел вам». (Евангелие от Матфея 28: 19-20).

Русское православное миссионерство имеет глубокие традиции и ведет свое начало фактически с $\mathrm{X}$ века, т.е. с момента принятия христианства Русью. Во второй половине XIX в. для официального православия в пределах своего «канонического пространства» определились главные приоритеты в области миссионерской деятельности: проповедь среди последователей иноверных исповеданий, возвращение «отпавших» от церкви, т.е. старообрядцев и сектантов, и охрана «истинного православия».

В Оренбургской епархии работа православных миссионеров среди населения, поликонфессионального по своему составу, была особенно актуальной. Сохранилось большое количество документов о деятельности миссионеров среди оренбургского старообрядчества (это к вопросу о своеобразности оренбургского региона).

Среди разнообразия архивных источников можно выделить основные группы документов.

Статистические источники, несомненно, представляют большую ценность, поскольку включают ведомости о численности старообрядцев и единоверцев, раскольнических скитов и молитвенных домов, сведения о количестве присоединившихся к официальному православию и отпавших от него. Данная группа позволяет определить конфессиональный состав населения Оренбургской епархии, динамику численности старообрядцев, количественные изменения внутри старообрядческих согласий и толков, возрастной и социальный состав староверческого населения. Статистические сведения содержатся в Российском государственном историческом архиве (РГИА), в фондах Сипягина (Ф. 721) и Департаменте Духовных дел иностранных исповеданий (Ф. 821); в Центральном государственном историческом архиве Республики Башкортостан (ЦГИА РБ) в фонде Оренбургского губернского правления (Ф. И-1). Значительный массив данного вида источника хранится в Государственном архиве Оренбургской области (ГАОО) в фондах Канцелярии Оренбургского гражданского губернатора (Ф. 10), Канцелярии Оренбургского генерал-губернатора (Ф. 6), Оренбургской духовной консистории (Ф. 173), Оренбургского губернского правления (Ф. 11) [4, л. 5-11].

Статистические ведомости составлялись как духовным, так и гражданским ведомствами. Однако отмечается их существенное расхождение в показателях. На наш взгляд, данные уездных исправников носили более объективный характер, но и они не отражали реальной численности оренбургского старообрядчества [5, л. 1-144].

Несовершенство методик сбора информации, скрытность самих раскольников, стремление властей занизить показатели влияли на достоверность и объективность представленных данных. Несмотря на это, статистические ведомости являются уникальным источником по истории и развитию староверия в России вообще и в Оренбургской епархии в частности.

Основу обширного комплекса архивных источников по истории противораскольнической деятельности Русской православной церкви в Оренбургской епархии составляют делопроизводственные материалы гражданских и церковных ведомств, хранящиеся в фондах архивов регионального и федерального значения.

Делопроизводственная документация по исследуемой тематике характеризуются обилием разного рода указов, переписки, прошений, рапортов и т.д. Из многообразия разновидностей источников мы можем выделить донесения нижестоящих лиц вышестоящим, деловую переписку местных светских и епархиальных властей между собой и центральными учреждениями. Особую группу, на наш взгляд, составляют епар- 
хиальные отчеты и представленные церковными властями сведения для губернаторских отчетов.

Донесения нижестоящих лиц представлены преимущественно рапортами священников, благочинных и миссионеров на имя Преосвященного, прошениями, миссионерскими отчетами и дневниками. Основная масса таких документов сосредоточена в фондах: Ф. 173 - Оренбургской Духовной Консистории; Ф. 174 - Канцелярии епископа Оренбургского и Уральского; Ф. 175 - Оренбургского епархиального комитета православного миссионерского общества Государственного архива Оренбургской области (ГАОО).

Ценность и информативность данного вида документов определена, на наш взгляд, тем, что в Оренбургской епархии до конца XIX в. специально подготовленных сотрудников-миссионеров не было. Обязанность вести проповедническую работу среди «раскольников» была возложена на приходских священников. Поэтому их донесения включали в себя информацию о наиболее интересных случаях присоединения старообрядцев к официальной православной церкви и в целом о повседневной пастырской работе среди своих прихожан [6, л. 16-39; 7, л. 2].

Рапорты миссионеров также составлялись на имя епархиального архиерея и сообщали о проведенных собеседованиях, миссионерских поездках, движении раскола на местах и т.д. Рапорты освещали конкретное событие или проблему. Часто донесение священника или миссионера становилось основой для начала целого дела. Согласно установленным правилам, миссионер, в случае обнаруженных им противозаконных действий в отношении православия, имел право обратиться за помощью к гражданским властям только через епископа. Такие дела могли включать в себя другие группы источников - статистические (о количестве старообрядцев, числе присоединенных к православной церкви), нормативноправовые [8, л. 7; 9, л. 2-4 об.].

Такого рода документы содержат информацию, которая свидетельствует о распространенном порой глубоком невежестве и суевериях в среде верующих. В этом отношении показательно дело из фонда Канцелярии Оренбургского гражданского губернатора (Ф. 10), где, по донесению священника Дмитрия Неаполитанова (будущего окружного миссионера), некий раскольник Павел Егоров Протисов в беседе с ним заявил, что «без чувственного креста и старой веры нельзя спастися, и что Цари это спознали и Великий Князь Константин Николаевич перешел в их согласие и женился сводом». Окружающим он внушал: «что крестная у Иисусу Христа была аллилуйа, а крестный - Иоанн Креститель, они и записаны в метрику» [10, л. 1 об.].

Ежегодные отчеты епархиальных и окружных миссионеров подавались Преосвященному по истечении года. Они представляли собой подробное описание предпринятых миссионерами маршрутов в «зараженные расколом» и сектантством приходы епархии и проведенных мероприятиях. В основном это были проповеди, публичные и частные собеседования, распространение книг и брошюр полемического и нравственного содержания, а также проведение курсов для подготовки «ревнителей православия» $[8$, л. 7]. Информация излагалась в повествовательной форме. Особое внимание в отчетах уделялось изложению хода бесед со старообрядцами. Указывалось их количество, тематика, длительность и реакция слушателей. Отчеты содержат важные сведения о повседневных миссионерских буднях, взаимоотношениях сотрудников миссии с приходским священством, данные о количестве присоединенных к православию старообрядцев, позволяющие в дальнейшем проанализировать эффективность деятельности внутренней миссии на территории епархии. В них представлена дополнительная информация о местах проживания старообрядцев, их численности, принадлежности к согласию. В своих донесениях миссионеры указывали на трудности, с которыми им приходилось сталкиваться: обширность епархии, дороговизна проезда, недостаток библиотек, некомпетентность приходских священников. Однако исследователю необходимо учитывать то, что отчет был предназначен для вышестоящего начальства и являлся показателем успешности миссионерской деятельности. События, излагаемые в отчете, подавались в выгодном свете исключительно для самого миссионера $[11$, л. $16 ; 12$, л. 2-8].

На местах помощь и поддержку православным миссионерам оказывали их сотрудники. В отличие от миссионеров, которые посещали приходы в лучшем случае 2 раза в год, сотрудники должны были оказывать влияние на старообрядцев ежедневно, посредством бытового общения. Результаты своей деятельности они фиксировали в дневниках. Поэтому данный источник представляет собой подробный рассказ об их повседневном общении с раскольниками, с изложением содержания бесед. При описании использовались элементы диалога. Кроме того, в виде таблицы сотрудник должен был заполнять графы, в которых отмечал местность, время прибытия и отьезда миссионера, продолжительность и содержание собеседований и мероприятий [13, л. 5].

В ходе работы с этими документами нужно учитывать их субъективную сторону и проверять старообрядческими источниками.

Деловая переписка церковных и гражданских ведомств между собой и центральными властями представлена разного рода документами. Это инструкции и наставления миссионерам, правила увещевания раскольников, расследования о нарушениях, злоупотреблениях и неисполнении ими своих обязанностей, переписка между епархиальными архиереями о состоянии противораскольнической миссии в Оренбургской епархии и т.п. Основной пласт этих документов хранится в Государственном архиве Оренбургской области в фондах Ф. 173, 174, 175 и Ф. 10. А также в фондах Ф. 796 - Канцелярии Св. Синода, Ф. 797 - Канцелярии обер-прокурора Св. Синода, Ф. 1473 - Секретного комитета по делам раскола Российского государственного исторического архива (РГИА). Материалы фонда Ф. 1183 - Московской конторы Синода Российского государственного архива древних актов (РГАДА) позволяют воссоздать процесс делопроизводства в Секретно-Совещательных Комитетах по делам раскола. Фонд Ф. 1431 дел местных и судебных учреждений о старообрядцах и сектантах (РГАДА) - содержит сведения о порядке решения уголовных дел в отношении старообрядцев, совершивших преступление против веры. Общие сведения о состоянии старообрядчества, переписка представителей правительственных кругов по старообрядческому вопросу хранятся в фондах III Отделения Собственной Его Императорского Вели- 
чества Канцелярии (Ф. 109) Государственного архива Российской Федерации (ГАРФ).

Переписка светских и духовных властей содержит информацию, которая свидетельствует о тесном взаимодействии двух ведомств по вопросам миссионерской деятельности и вместе с тем о возникавших противоречиях, о разных точках зрения на эффективность используемых духовенством методов в борьбе с расколом [14, л. $1-19 ; 15$, л. 2].

Так называемые «Наставления миссионеров» представляют особый исследовательский интерес. В них епархиальным руководством формировался образ православного миссионера и стратегия его действий. Например, «Наставления», составленные миссионеру Уфимской епархии священнику Афанасию Попову от 1862 г., содержательно состояли из глав, которые раскрывали его общие обязанности, правила поведения (благоразумия) среди раскольников и методы их обращения в православие. В итоге миссионер должен был обладать высокими религиознонравственными качествами, глубокими познаниями в области учения Православной церкви и глаголемых старообрядцев. С ревностью выполняя свои обязанности приходского священника, миссионер должен был быть примером для подражания в любой сфере жизни, как религиозной, так и бытовой.

Представляя раскольников как «заблудших» людей, как «опасно больное дитя», миссионеру предлагалось избегать открытого осуждения, враждебности, а действовать «миролюбиво и кротко, как того требует христианская любовь, обязывающая оказывать помощь самым врагам» [16, л. 13]. Согласно инструкции, священник своими действиями сначала завоевывал авторитет окружающих старообрядцев, их доверие и только затем, в рамках собеседований, переходил к спорным церковным вопросам. Для этого «Наставления» по каждому предмету спора были снабжены подробным списком литературы и пособий, где можно было найти необходимую информацию.

В указанную группу делопроизводственных источников можно включить указы и распоряжения Святейшего Синода, Министерства Внутренних Дел, Оренбургской Духовной консистории. В местных и федеральных архивах накоплен огромный массив этой разновидности делопроизводственной документации. Источники требуют особого и более подробного исследования, так как они регулировали все сферы миссионерской работы в Оренбургской епархии.

Очередную группу делопроизводственной документации составляют ежегодные губернаторские и епархиальные отчеты. Они фиксировали информацию о состоянии раскола в регионе, взаимоотношениях духовенства и паствы и др. Этой документации присущ обобщающий характер. Собственно годовой губернаторский отчет включал в себя текстовую часть и Приложение (цифровые ведомости). На протяжении XIX в. ряд циркуляров МВД изменяли форму отчета. Этим объясняется то, что сведения о старообрядцах (подпункт о расколе) в его текстовой или основной части сначала помещались во II разделе «О суде, Полиции и народном здравии», а в 1853 г. в III разделе «Об общественном благоустройстве». В текстовую часть отчетов были включены данные об общем количестве «раскольников» в губернии, об «уклонившихся в раскол» и «присоединенных» к православию и единоверию из числа старообрядцев. Анализ текстов отчетов оренбургских губернаторов первой и второй половины XIX в. позволяет сделать вывод о том, что составители отчетов начала XIX в. ограничивались лишь общей цифрой указанных категорий. В отчетах последних десятилетий XIX в. сведения заключались в таблицы с указанием пола, сословия и старообрядческого толка [17, л. 145].

В Государственном архиве Оренбургской области епархиальные отчеты сосредоточены в фонде Оренбургской Духовной консистории (Ф. 173). Структура документа также представляла собой деление на подпункты, где помимо общего описания состояния епархии, данных о территории, количестве церквей, материальном положении и образовательном уровне священников, обязательно уделялось внимание проблеме раскола и борьбы с ним со стороны приходского духовенства и миссионеров. Отчеты Преосвященных середины XIX века ограничивались именно обобщающей информацией о старообрядчестве. В качестве причин, объясняющих силу и обширность раскола, называли как его активную пропаганду среди православных через ежедневное общение, так и «слабость мер против совратителей» со стороны гражданских властей [18, л. 1-5].

В 80-х - 90-х гг. XIX в. на фоне активизации православного миссионерства в Оренбургской епархии, в связи с открытием Оренбургского Комитета православного миссионерского общества, Противораскольнического Комитета и Михаило-Архангельского Братства, отчет стал включать обзор действий православных миссионеров и результаты их деятельности в виде количества присоединенных к православию или единоверию раскольников. Фактически документ включал сведения, которые подавали окружные и епархиальные миссионеры. Они в основном носили описательный характер, аналитическая сторона практически отсутствовала [19, л. 8-12].

В качестве материалов личного происхождения можно выделить личный фонд генерал-майора Ивана Васильевича Чернова (1825-1902), его «Заметки по истории Оренбургского края» (Ф. 167). В 1907 г. со значительными изменениями и сокращениями рукопись была опубликована в «Трудах» ОУАК. Только в настоящее время оренбургскому историку Д.А. Сафонову на основе рукописи и издания 1907 г. впервые удалось воссоздать полный текст воспоминаний [20]. Значение этого источника для исследования данной проблемы определяется целым рядом важных замечаний, оценок конкретных сюжетов. У Чернова особая, свойственная чиновному, служилому люду, шкала ценностей исторических знаний, ценности воспоминаний, ценности сведений, достойных упоминания. Источник носит субъективный характер, но «колоритно» иллюстрирует личное отношение представителей гражданских властей к явлению раскола в Оренбургском и Уральском казачьих войсках, раскрывает особенности психологии оренбургских старообрядцев середины XIX в.

Таким образом, архивные источники, несмотря на их субъективность (преимущественно они представлены документами церковных и гражданских ведомств, которые занимали исключительно негативную позицию по отношению к расколу и так и не смогли создать эффективную методику сбора сведений о его состоянии), являются для нас наиболее ценными. Они дают возможность изучить историю данной конфессиональной общности, выявить специфику ее развития в рамках Оренбургского региона 
и сами могут выступать в качестве объекта самостоятельного изучения.

Обзор источниковой базы по истории миссионерской деятельности Русской православной церкви второй половины XIX - начала XX в. позволяет сделать вывод о ее многообразии и содержательности. Мы полагаем, что представленные характеристики различных видов архивных источников помогут исследователям адаптироваться в указанном массиве документов. Вместе с тем заметим, что представленная классификация не является окончательной и может быть дополнена.

\section{Список литературы:}

1. Bender C. Practicing religions // The Cambridge companion to religious studies. Cambridge, 2012. P. 273-295.

2. Рижский старообрядческий сборник. Материалы по истории староверия. Вып. II. Рига: Старообрядческое общество Латвии, 2011. 328 с.

3. Таранец С.В. Старообрядчество в Российской империи (конец XVII - начало XX века). Т. 2: Старообрядчество в социокультурном аспекте / под ред. Г.В. Боряка. Институт истории Украины НАН Укра- ины; Музей истории и культуры старообрядчества Украины. Киев, 2013. 688 с.

4. Государственный архив Оренбургской области (ГАОО). Ф. 11. Оп. 11. Д. 1179.

5. ГАОО. Ф. 10. Оп. 8. Д. 97

6. ГАОО. Ф. 173. Оп. 5. Д. 8716.

7. ГАОО. Ф. 175. Оп. 2. Д. 23.

8. ГАОО. Ф. 173. ОП. 5. Д. 9409.

9. Оренбургский государственный архив Челябинской области (ОГАЧО). Ф. И-33. Оп. 1. Д. 3854.

10. ГАОО. Ф. 10. ОП. 8. Д. 154.

11. ГАОО. Ф. 10. ОП. 2. Д. 111.

12. ГАОО. Ф. 173. Оп. 5. Д. 8885 .

13. ГАОО. Ф. 173. ОП. 1. Д. 90.

14. Российский государственный исторический архив (РГИА). Ф. 796. ОП. 151. Д. 1627.

15. РГИА. Ф. 381. ОП. 2. Д. 2516.

16. ГАОО. Ф. 174. ОП. 1. Д. 367.

17. ГАОО. Ф. 10. Оп. 2. Д. 66.

18. ГАОО. Ф. 173. Оп. 4. Д. 6767.

19. ГАОО. Ф. 10. Оп. 2. Д. 112.

20. Записки генерал-майора [Оренб. казачьего войска] Ивана Васильевича Чернова // Тр. Оренб. учен. арх. комис. Оренбург, 1907. Вып. 18. С. 15-224.

\section{ARCHIVAL SOURCES OF THE RUSSIAN ORTHODOX CHURCH MISSIONARY ACTIVITY HISTORY AMONG THE OLD BELIEVERS OF THE ORENBURG DIOCESE OF THE SECOND HALF OF THE XIX - EARLY XX CENTURIES}

(C) 2018

Kamzina Alina Dzhanarovna, candidate of historical sciences, associate professor of History of Russia Department Orenburg State Pedagogical University (Orenburg, Russian Federation)

Abstract. The historical period considered in this paper is one of the important periods for the economic, political and spiritual development of the Russian state. The Orenburg Region at this stage was a multi-confessional region, where, despite the leading role of the Russian Orthodox Church, both non-Christian and Christian denominations, including a variety of old believers' consent and sectarianism, were spread. In this regard, the anti-sectarian missionary activity of the official Orthodoxy aimed at both the old believers and sectarians became particularly relevant. Archival documents in the collections of Federal and regional archives form the basis of this problem study. The paper presents an overview of unpublished sources and their source analysis. The author analyses such groups of archival sources as statistical materials, records of management sources, among which a special place is occupied by the Governor's and diocesan reports, documents of personal origin, legislative materials. Among these groups of sources, the most valuable ones are records of civil and spiritual departments. The review allows to conclude about the variety of types of archival documents and their various informative features. The presented classification is not final and can be supplemented.

Keywords: Russian Orthodox church; Orthodox missionary work; old belief; sectarianism; statistical papers; office sources; missionary; Orenburg diocese; diocesan report; Governor's report; Orthodox missionary brotherhood.

УДК 27

DOI 10.24411/2309-4370-2018-14217

Статья поступила в редакцию 05.08.2018

\section{МАТЕРИАЛЫ БЕЛОЭМИГРАНТСКИХ ЦЕРКОВНЫХ ОРГАНИЗАЦИЙ В КИТАЕ КАК ИСТОЧНИК ПО ИСТОРИИ ПРАВОСЛАВНОЙ ЦЕРКВИ}

(C) 2018

Дроботушенко Евгений Викторович, кандидат исторических наук, доцент, декан исторического факультета

Ланцова Юлия Николаевна, кандидат исторических наук, доцент кафедры истории

Забайкальский государственный университет (г. Чита, Российская Федерация)

Аннотация. В статье рассматриваются различные аспекты истории православной церкви в Китае на основе богатейшего источника - материалов белоэмигрантских церковных организаций, собранных в одно объемное дело фонда 9145 «Коллекции отдельных документов различных эмигрантских организаций» Государственного архива Российской Федерации. Данное дело содержит в себе как переписки по отдельным вопросам, так и различного рода листовки, брошюры, газетные статьи, афиши, объявления, отчеты, ведомости, заметки с характеристикой различных аспектов православной истории и охватывает временной период с 1924 